\title{
Revision of the genus Xyalaspis Hartig, 1843 (Hymenoptera: Figitidae: Anacharitinae) in the Western Palaearctic
}

\section{Noel MATA-CASANOVA}

Universitat de Barcelona, Facultat de Biologia, Departament de Biologia Animal, Avda. Diagonal 645, E-08028 Barcelona (Spain) feofitotu@gmail.com (corresponding author)

Jesús SELFA Universitat de València, Facultat de Ciències Biològiques, Departament de Zoologia, Campus de Burjassot-Paterna, Dr. Moliner 50, E-46100 Burjassot (València), (Spain) jesus.selfa@uv.es

Juli PUJADE-VILLAR

Universitat de Barcelona, Facultat de Biologia, Departament de Biologia Animal, Avda. Diagonal 645,

E-08028 Barcelona (Spain) jpujade@ub.edu

Published on 27 March 2015

KEY WORDS

Western Palaearctic, revision, new synonym new combination new species.

Mata-Casanova N., Selfa J. \& Pujade-Villar J. 2015. - Revision of the genus Xyalaspis Hartig, 1843 (Hymenoptera: Figitidae: Anacharitinae) in the Western Palaearctic, in Daugeron C., Deharveng L., Isaia M., Villemant C. \& Judson M. (eds), Mercantour/Alpi Marittime All Taxa Biodiversity Inventory. Zoosystema 37 (1): 31-43. http://dx.doi.org/10.5252/z2015n1a2

\section{ABSTRACT}

A revision of Xyalaspis Hartig, 1843 (Hymenoptera: Anacharitinae) in the Western Palaearctic region is given. Xyalaspis spinigera Reinhard, 1860 and Xyalaspis subulifera (Thomson, 1862) are synonymized with Xyalaspis laevigata Hartig, 1843 and Xyalaspis rugosa Hartig, 1843 respectively, and their distribution areas are extended. A new species Xyalaspis pseudolaevigata n. sp. is described from France. One species previously assigned to the genus Xyalaspis, X. laevis (Hedicke, 1914), is transferred to Aegilips Haliday, 1835. Diagnostic characters are illustrated and data about biology, distribution and morphological variability of the studied species are presented and discussed. A key to differentiate the Western Palaearctic species of Xyalaspis is included. 


\begin{abstract}
RÉSUMÉ
Révision du genre Xyalaspis Hartig, 1843 (Hymenoptera: Figitidae: Anacharitinae) dans le Paléarctique occidental.

Le genre Xyalaspis Hartig, 1843 (Hymenoptera: Anacharitinae) est révisé pour le Paléarctique occidental. Xyalaspis spinigera Reinhard, 1860 et Xyalaspis subulifera (Thomson, 1862) sont mis en synonymie avec Xyalaspis laevigata Hartig, 1843 et Xyalaspis rugosa Hartig, 1843 respectivement, et l'aire de distribution de ces espèces est étendue. Une nouvelle espèce est décrite pour la France : Xyalaspis pseudolaevigata n. sp. Xyalaspis laevis (Hedicke, 1914), est transféré au genre Aegilips Haliday, 1835. Les caractéristiques diagnostiques plus importantes sont illustrées. Des données sur la biologie, la distribution et la variabilité morphologique des espèces sont discutées. Une clé pour différencier les espèces ouest paléarctiques est rédigée.

MOTS CLÉS révision, nouvelle synonymie, combinaison nouvelle, espèce nouvelle.
\end{abstract}

This study focuses on the Western Palaearctic Xyalaspis species and is part of a worldwide review of the genus Xyalaspis. The genus has already been revised for the American continent (Mata-Casanova et al. 2014a), and also species of the Eastern Palaearctic, Indomalayan and Australian areas have been revised (Mata-Casanova et al. 2014b). In this study $X$. spinigera is synonymized with $X$. laevigata and X. subulifera with $X$. rugosa. Moreover, $X$. laevis is transferred to genus Aegilips, and a new species, X. pseudolaevigata Mata-Casanova \& Pujade-Villar, n. sp. is described. In order to summarize this information, an identification key for the Palaearctic Xyalaspis species is presented.

\section{ABREVIATIONS}

\section{Anatomy}

F1-F12 First and subsequent flagellomeres;

LOL Lateral-frontal ocellar distance (distance between the edges of the lateral and frontal ocelli);

OOL Ocular-ocellar distance (shortest distance between the inner margin of the compound eye and the outer edge of the posterior ocellus);

POL Post-ocellar distance (distance between the inner margins of the posterior ocelli);

T1-T7 Metasomal tergites 1 to 7. species have been cited from the Western Palaearctic: Xyalaspis armata (Giraud, 1860), X. hyalina Belizin, 1951, X. laevigata Hartig, 1843, X. laevis (Hedicke, 1914), X. petiolata Kieffer, 1901, X. rugosa Hartig, 1843, X. spinigera (Reinhard, 1860) and $X$. subulifera (Thomson, 1862).

The only revision of Palaearctic Anacharitinae including the genus Xyalaspis was undertaken by Dalla-Torre \& Kieffer (1910). Belizin (1951) studied the Russian species, citing $X$. armata and describing a new species, $X$. hyalina. Fergusson (1986) reviewed the British species and described the biology of $X$. petiolata attacking the aphid-feeding larvae of Hemerobius sp. and Wesmaelius subnebulosus (Neuroptera: Hemerobiidae). Recently Ros-Farré \& Pujade-Villar (2011) transferred Omalaspis laevis Hedicke, 1914 to the genus Xyalaspis. All the original descriptions are very short, the characters mentioned are not homogeneous and some important characters are not taken into account; for these reasons, a revision of the type material was needed for the precise differentiation of these species.

\section{Depositories \\ CNC Canadian National Collection of Insects, Arachnids and Nematodes, Ottawa, Canada; \\ MNHN Muséum national d'Histoire naturelle, Paris, France; \\ NHM The Natural History Museum, London, UK; \\ UB Universitat de Barcelona, Barcelona, Spain; \\ ZIN Zoological Institute of the Russian Academy of Sciences, Saint Petersburg, Russia; \\ ZSM Zoologische Staatssammlung München, Munich, Germany.}

\section{MATERIAL AND METHODS}

The material identified in this study belongs to the CNC, the MNHN and the NHM; it has been deposited in the institutions mentioned above and in UB. The material provided by the MNHN was collected with Malaise traps in the Mercantour National Park in the Mediterranean Alps (France) during the 
ATBI Mercantour project; detailed information on the sample code (given in brackets for each specimen), the corresponding trap geographic coordinates and the main vegetation present at sampling site is given in Deharveng et al. (2015, this volume). In total, 58 specimens were studied, comprising 48 males and 10 females. All Xyalaspis types have been examined, but in this study we only make reference to the type material of the Palaearctic species of the genus: $X$. armata, $X$. hyalinus, $X$. laevis, $X$. laevigata, $X$. petiolata, $X$. rugosa and $X$. spinigera. Species are treated in alphabetical order.

Morphological terms used are from Richards (1977) and Ronquist (1995). All measurements are relative except for the body length. Antennal formula includes scape, pedicel and flagellomere length and relative width in brackets.

The specimens were studied at the "Serveis Científico-Tècnics de la Universitat de Barcelona" using stereomicroscopy and environmental scanning electron microscopy. A field-emission gun environmental scanning electron microscope (FEI Quanta 200 ESEM) was used for high-resolution imaging without gold-coating of the specimens in order to preserve the material.

\section{SYSTEMATICS}

Family Figitidae Thomson, 1862

Subfamily ANACHARITINAE Thomson, 1862

Genus Xyalaspis Hartig, 1843

Xyalaspis armata (Giraud, 1860)

(Figs 1A; 2A; 4A)

Aegilips armatus Giraud, 1860: 173 (female).

Xyalaspis armata - Kieffer 1901: 161.

TYPE MATERIAL. - Holotype. + with the following labels: "Holotype" (red label); "Muséum Paris, coll. Giraud 1877" (white label); "Holotype of Aegilips armatus Giraud, det. N. D. M. Ferguson, 1981" (white label); "Xyalaspis armatus (Giraud) + Kieffer, 1901, det. N. Mata-Casanova, 2012" (white label). (Deposited in MNHN).

Biology. - Unknown.

Distribution. - Palaearctic. Known from Sweden, Britain (Kieffer 1901); Germany, Austria (Dalla Torre \& Kieffer 1910); Russia (Belizin 1951); Ireland (Ferguson 1986); Spain (Ros-Farré \& Pujade-Villar 1997).

DiAGNOSIS. - Species with completely smooth mesoscutum similar to $X$. atemiensis Ashmead, 1904 and X. pilosa Mata-Casanova, 2013, from which it differs by the lack of internal carinae in the mesoscutum (notauli internally carinated in X. atemiensis and X. pilosa).

\section{REDESCRIPTION (FEMALE ONLY)}

Length

Body $3.1 \mathrm{~mm}$. Wings $3.1 \mathrm{~mm}$. Antennae $2.8 \mathrm{~mm}$.

\section{Coloration}

Head, mesosoma and metasoma black. Mandibles yellowish brown with darker teeth. Antennae yellowish-brown. Legs yellowish brown with darker coxae. Wing venation yellow.

\section{Head}

Width of head $2 \times$ its height in front view and $1.3 \times$ its length in dorsal view. Face smooth, shiny and pubescent, with abundant piliferous punctures. Malar sulcus present, coriaceous, $0.7 \times$ height of compound eye. Transfacial line $1.2 \times$ height of compound eye. Diameter of toruli larger than inter-toruli distance and that of torulus to compound eye. Clypeus short; smooth, glabrous and convex. Occipital and postocular carinae absent. Compound eyes almost glabrous except for a few short setae. POL:OOL:LOL ratio $=8: 6: 3$, ocelli diameter 2 . Frons smooth, shiny and shortly pubescent with some punctures.

\section{Antennae}

Flagellomeres cylindrical and hairy. Antennal formula: 12(5), 4.5(4), 11.5(3), 12(3), 10.5(3.5), 10(3.5), 9.5(4), 9(4), 8(4), 6(4), 6(4), 6(4), 12(4). Placodeal sensilla start at F2.

\section{Mesosoma}

Pronotum carinated in its lower part and smooth in the upper part (Fig. 2A). Mesoscutum $1.2 \times$ wider than long in dorsal view. Mesoscutum smooth and shiny, almost glabrous except for few scarce setae and punctures. Notauli complete but weak, without internal transverse ridges (Fig. 1A); median mesoscutal furrow short and weakly impressed. Parapsidal signum and parascutal sulcus absent. Scutellum as long as mesoscutum in dorsal view. Scutellar foveae alutaceous, basally defined by a carina. Interfoveal line complete. Lateral pits of scutellar foveae weakly excavated. Scutellar spine with parallel sides and ending in a spike; nearly one-half of mesoscutellum length and slightly projecting upwards in lateral view. Mesopleuron smooth, shiny and glabrous, with weak basal transverse carinae. Mesopleural triangle smooth and pubescent. Propodeum heavily areolate; central area delimited by two longitudinal carinae and internally divided by some incomplete and weak internal carinae.

\section{Wings}

Pubescent. Radial cell of forewing closed, $2.2 \times$ longer than wide. Marginal pubescence of forewing denser in apical third.

\section{Metasoma}

Petiole wider than long, carinated on all sides (Fig. 4A). Third abdominal tergum $2.2 \times$ longer than fourth abdominal tergum in dorsal view. T5 and T6 visible in dorsal view. Anterior margin of T4-T7 punctuate.

\section{Xyalaspis hyalina Belizin, 1951}

(Figs 1B;2C)

Xyalaspis hyalina Belizin, 1951: 574 (male).

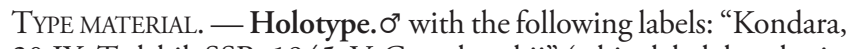
20.IX, Tadzhik SSR, 1945, V. Gussakovskij" (white label, handwritten, in Cyrillic); "Holotypus Xyalaspis hyalinus o", V. Belizin det" (red label, handwritten), "Xyalaspis hyalinus, V. Belizin, Kovalev det 1996” (white label). (Deposited in ZIN). 
Other material examined. - Cyprus: Pera Pedri Krios R, 10.IX.1937, G. A. Mavromoustakis, B. M. 1987-808, $10^{7}$ (NHM).

Biology. - Unknown.

Distribution. - Palaearctic. Known from Russia, Kazakhstan, Tajikistan (Belizin 1951), Armenia (Belizin 1961), first record from Cyprus.

Diagnosis. - Species close to $X$. laevigata, but it can be distinguished by the presence of incomplete notauli, scutellar spine slightly projected upwards in lateral view and antennae longer than the body (notauli weakly impressed in $X$. laevigata but complete, scutellar spine straight in lateral view and antennae shorter than the body).

\section{REDESCRIPTION (MALE ONLY)}

Length

Body $2.8 \mathrm{~mm}$. Wings $2.6 \mathrm{~mm}$. Antennae $3.2 \mathrm{~mm}$.

\section{Coloration}

Head, mesosoma and metasoma black. Mandibles yellowishbrown with darker teeth. Antennae yellowish-brown. Legs yellowish-brown with darker coxae. Wing venation yellow.

\section{Head}

Width of head $1.2 \times$ its height in front view and 1.8 its length in dorsal view. Face smooth, shiny and pubescent, with abundant piliferous punctures. Malar sulcus present, coriaceous, $0.5 \times$ height of compound eye. Transfacial line subequal to height of compound eye. Diameter of toruli equal to inter-toruli distance and larger than torulus to compound eye distance. Clypeus not apparent; smooth, glabrous and convex. Occipital and postocular carinae absents. Compound eyes completely glabrous. POL:OOL:LOL ratio = 6:4:2.5, ocelli diameter 2 . Frons smooth, shiny and shortly pubescent with some punctae.

\section{Antennae}

Flagellomeres cylindrical and hairy. Antennal formula: 25(11), 9.5(9.5), 25(8), 25.5(8.5), 26(8.5), 24.5(8.5), 26(8), 26(8), 25(8), 25(7.5), 25(7), 23(7), 23(7), 28(6). Placodeal sensilla start at F1.

\section{Mesosoma}

Pronotum carinated in its lower part and smooth on its upper side (Fig. 2C). Mesoscutum $1.2 \times$ wider than long in dorsal view. Mesoscutum smooth, pubescent and punctate, with alutaceous sculpture at base of notauli. Notauli weakly impressed and lacking internal carinae, being replaced by weak carinated sculpture at anterior third of the mesoscutum (Fig. 1B); median mesoscutal furrow weakly impressed. Parapsidal signum and parascutal sulcus absent. Scutellum 0.8 as long as mesoscutum in dorsal view. Scutellar foveae smooth, basally defined by a carina and including an oblique internal carina. Interfoveal line complete. Lateral pits of scutellar foveae distinct. Scutellar spine narrowing apically; slightly projected upwards in lateral view. Mesopleuron smooth, shiny and glabrous, basally carinated. Mesopleural triangle smooth and pubescent. Propodeum heavily areolate and pubescent; central area divided by a longitudinal median carina and a several transverse carinae defining eight cells.

\section{Wings}

Pubescent. Radial cell of the forewing closed, $2.4 \times$ longer than wide. Marginal pubescence of forewing denser in its apical third.

\section{Metasoma}

Petiole as long as wide, dorsally smooth and laterally and ventrally carinated. T3 $3.6 \times$ longer than T4 in dorsal view. T5 and T6 are visible in dorsal view. Metasoma smooth and glabrous.

\section{Xyalaspis laevigata Hartig, 1843 \\ (Figs 1C; 2B; 3C, D)}

Xyalaspis laevigatus Hartig, 1843: 417 (male).

Aegilips spinigera Reinhard, 1860: 221 (male).

Xyalaspis laevigata - Förster 1869: 361.

Xyalaspis spinigera - Kieffer 1901: 161.

TYPE MATERIAL. - Holotype. 0 " with the following labels: "Xyalaspis laevigatus" (white label, handwritten); "Weld, 1931" (red label, handwritten); "Holotype \& Xyalaspis laevigatus Hartig, 1843" (red label); "Xyalaspis laevigata Htg. C. Restrepo-Ortiz det. 2012" (white label). Deposited in ZSM.

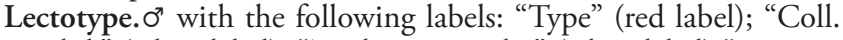
H.Rhd." (white label); "Zool. Mus. Berlin" (white label) "Lectotypus Aegilips spinigerao" Reinhard, 1860, desig. N. Mata-Casanova, 2012" (red label); "Xyalaspis spinigera (Reinhard) o" Kieffer, 1901, det. N. Mata-Casanova, 2012" (white label). Deposited in Museum für Naturkunde.

Other MATERIAl EXAMINED. - Spain. $6 \mathrm{~km}$ Nerja (Costa del Sol), Málaga, 200 m, 6.VI.1988, coll. L. Masner, $10^{*}$ (CNC). Montán, Castellón, 10.VIII.1988, coll. J. Selfa, $20^{7}$ (UB). Lafortunada, Huesca, 4.VII.1995, coll. J. Pujade-Villar, $10^{7}$ (UB).

Andorra. Santa Coloma, Malaise trap, IX.1992, coll. J. PujadeVillar, 1 ㅇ (UB).

France. Mt. Ventoux, Vaucluse, 1700 m, 27.VIII.1988, coll. Bouček, 1 으 (BMNH). Vallon de Sestrière, Saint-Dalmas-le-Selvage, Alpes-Maritimes, Malaise trap, 1421 m, 22.IX-7.X.2009 (M09SES1400-T7-M2), 1 우 (MNHN); same locality, Malaise trap, 1437 m, 19.VIII-22.IX.2009 (M09-SES1400-T6-M1), 1 ㅇ (MNHN); same locality, same trap, 22.IX-7.X.2009 (M09SES1400-T6-M1), $10^{7}$ (MNHN); same locality, Malaise trap, 1966 m, 23.VII-07.VIII.2009 (M09-SES2000-T4-M1), 1 \% (MNHN). Col de Salèse, Valdeblore, Alpes-Maritimes, Malaise trap, 2032 m, 24.VII-13.VIII.2009 (M09-BOR2000-M2-T4), $20^{7}$ (MNHN); same locality, same trap, 27.VIII-18.IX.2009 (M09BOR2000-M2-T6), 20" (MNHN).

Germany. Scheffau, Bayern, 800 m, 24.VII.1958, coll. D. Townes, $10^{7}$ (CNC). Schliersee, Bayern, 1100 m, 28.VII.1958, coll. D. Townes, $10^{\pi}$ (CNC).

Norway. Buolamalia, Detsika, Alta, 24.VI-16.VII.1996, coll. Lars Ove Hansen, $10^{\top}$ (CNC)

Romania. Kiruly Valley, Hargita, Co., 15.VIII.2000, coll. Zoltán Ács, $10^{*}$ (CNC).

Iran. Gajert, Tehran, 23.VI.1978, coll. J. T. Huber, $10^{\top 7}$ (CNC).

Biology. - Unknown.

Distribution. — Palaearctic. Known from Austria (Hartig 1843); first records for Spain, Andorra, France, Romania, Norway and Iran. 

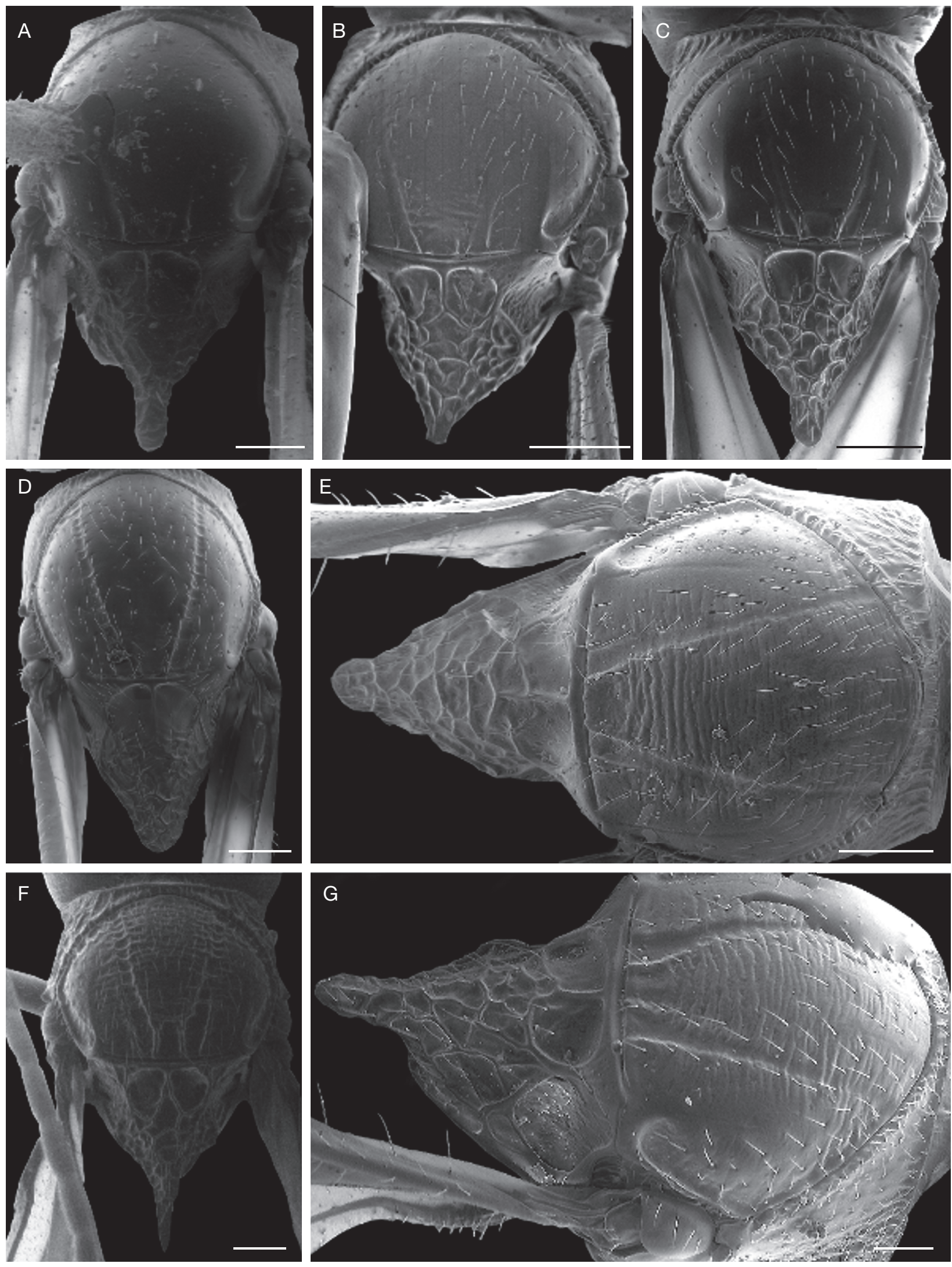

FIG. 1. - Mesoscutum in dorsal view of: A, Xyalaspis armata (Giraud, 1860); B, Xyalaspis hyalina Belizin, 1951; C, Xyalaspis laevigata Hartig, 1843; D, Xyalaspis petiolata Kieffer, 1901; E, G, Xyalaspis pseudolaevigata Mata-Casanova \& Pujade-Villar, n. sp.; F, Xyalaspis rugosa Hartig, 1843. Scale bars: A-D, F, 200 um; $\mathrm{E}, \mathrm{G}, 100 \mu \mathrm{m}$. 
DiAGNOSIS. - Species having a weak carinated sculpture at the base of notauli like Xyalaspis hyalina; it can be distinguished by the presence of complete notauli and having antennae shorter than the body (complete notauli and antennae longer than the body in $X$. hyalina).

\section{REDESCRIPTION}

\section{Length}

Body: $2.9 \mathrm{~mm}$. Wings: $2.7 \mathrm{~mm}$. Antennae: $2.8 \mathrm{~mm}\left(\mathrm{o}^{7}\right)$, $2.6 \mathrm{~mm}($ (\%).

\section{Coloration}

Head, mesosoma and metasoma black. Mandibles yellowishbrown with darker teeth. Antennae yellowish-brown. Legs yellowish-brown with darker coxae. Wing venation yellow.

\section{Head}

Width of head $1.3 \times$ height in front view and 2 its length in dorsal view. Face smooth, shiny and pubescent, with abundant piliferous punctures. Malar sulcus present, coriaceous, $0.6 \times$ height of compound eye. Transfacial line $1.2 \times$ height of the compound eye. Diameter of toruli larger than inter-toruli distance and torulus to compound eye distance. Clypeus not apparent; smooth, glabrous and convex. Occipital and postocular carinae absents. Compound eyes almost glabrous except for several short setae concentrated in central eye. In females, POL:OOL:LOL ratio $=7: 6: 2.5$, ocelli diameter 2 ; in males, POL:OOL:LOL ratio $=7: 4: 3$, ocelli diameter 3.5. Frons smooth, shiny and shortly pubescent with some punctures.

\section{Antennae}

Flagellomeres cylindrical and hairy. Male antennal formula (type material only has from scape to F4, but other specimens with complete antennae have been used to complete the antennal formula): 10(3.5), 4(3.5), 10(3), 10(3), 10(3), 9(3), 9(3), 9(3), 8(3), 8(3), 7(3), 7(3), 6(3), 9(3). Female antennal formula: 11(3.5), 4(3), 10(2.5), 11(3), 9.5(3), 9.5(3), 8(3), 7.5(3), 7(3), 5(3), 5(3), 5(3), 9(3). Placodeal sensilla start at $\mathrm{F} 2$ in females and at $\mathrm{F} 1$ in males.

\section{Mesosoma}

Pronotum carinated in its lower part and on its margins but alutaceous in its upper part (Fig. 2B). Mesoscutum 1.2 wider than long in dorsal view. Mesoscutum smooth, pubescent and punctate, with alutaceous sculpture at base of notauli (Figs 1C; 3C), mesoscutum almost entirely carinated in some specimens (Fig. 3D). Notauli complete but weakly impressed, fading at anterior mesoscutum, not internally carinated; median mesoscutal furrow weakly impressed. Parapsidal signum and parascutal sulcus absent. Scutellum length subequal to mesoscutum length (22:23) in dorsal view. Scutellar foveae smooth, basally defined by a carina, an oblique internal carina present in some specimens. Interfoveal line complete. Lateral pits of scutellar foveae weakly impressed. Scutellum narrowing at base of scutellar spine; scutellar spine with parallel sides, projected from scutellum and straight in lateral view; between one-quarter to one-third of entire scutellum length. Mesopleuron smooth, shiny and glabrous, with basal trans- verse carinae. Mesopleural triangle smooth and pubescent. Propodeum heavily areolate and pubescent; central area divided by a longitudinal median carina and a transverse carina which define two small, lower cells and two larger upper cells crossed by weaker transverse ridges.

\section{Wings}

Radial cell of forewing closed, 2.7 longer than wide. Marginal pubescence of forewing denser in its apical third.

\section{Metasoma}

Petiole longer than wide, ventrally and laterally carinated and dorsally smooth. T3 $2.5 \times$ longer than T4 in dorsal view. T5 and T6 visible in dorsal view. Anterior margin of T4-T7 punctate.

\section{REMARKS}

Although Hartig's (1843) original description mentions the holotype as being a female, it has 14 antennal segments and the metasomal shape of a male, so we concluded that Hartig was in error and the holotype of $X$. laevigata is a male.

\section{Xyalaspis petiolata Kieffer, 1901}

(Figs 1D; 2E; 3A, B; 4B)

Xyalaspis petiolata Kieffer, 1901: 161 (male).

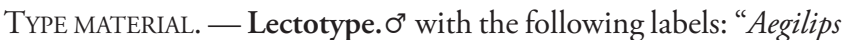
subulifera JH" (white label, handwritten), "Subulifera JH" (white label, handwritten), "Xyalaspis petiolata Kieffer, det. R. B. Benson 1940" (white label), "Lectotype Xyalaspis petiolata det N. D. M. Fergusson, 1981" (white label), "Xyalaspis petiolata Kieffer, 1901, ơ, det. J. P-V 2012” (white label). (Deposited in NHM).

OTHER MATERIAL EXAMINED. - UK. Glenasmole,, IX.1937, coll. A. W. Stelfox, $10^{\text {" }}$ (NHM). Glenn Cova, 11-30.VI.1939, coll. I. E. \& R. B. Benson, $10^{\prime \prime}$ (NHM). Waverley, 7.X.1952, H. W. Daltry, M. W. R de V, Graham, coll. 1 ㅇ (NHM). New Forest, 5.IX.1958, H. W. Daltry, M. W. R de V, Graham coll. $10^{7}$ (NHM). New Forest, 18.IX.1958, H. W. Daltry, M. W. R de V, Graham coll. $10^{7}$ (NHM). SW Lough Rea, 30.V.1960, H. W. Daltry, M. W. R de V, Graham coll. $10^{7}$ (NHM). Beinn Eighe Forest, 30.V.1961, coll. R. B. Benson, $10^{7}$ (NHM). Kinlochewe, 1-8. VI.1961, coll. R. B. Benson, 10' (NHM). Shieldaig, 7.VI.1961, coll. R. B. Benson, 1 ㅇ (NHM). Esher Common, Surrey, 30.V.70, coll. Bouček, $10^{7}$ (NHM). Craswall, Hereford, 23-24.VI.73, 1 우 (NHM). Abbots Moss, 6.II.1974, M. R. Shaw, $10^{7}$ (NHM). Abbots Moss, 3.X.1974, coll. M. R. Shaw, $10^{7}$ (NHM). Burnham Beeches, Buckinhamshire, 3.VIII.75, Bouček, 1 우 (NHM). Northants, Spratton, In Malaise trap, VIII.1975, coll. I. \& P. Gauld, $20^{\circ}$ (NHM) Fife Tentsmuir Nat, 16.VII.1977, coll. Noyes, Rogers \& Huddleston, $10^{7}$ (NHM). Angus Airlie Castle, 19.VII.1977, coll. Noyes, Rogers \& Huddleston, $20^{7}$ (NHM). Barton Mills, Suffolk, 7.IX.1977, coll. J. S. Noyes, 1 ( (NHM).

Ireland. Manor Kilbride, 19.VII.1950, coll. A. W. Stelfox, $10^{\prime \prime}$ (NHM). France. Col de Salèse, Valdeblore, Alpes-Maritimes, $2058 \mathrm{~m}$, Malaise trap, 18.IX-05.X.2009 (M09-BOR2000-M1-T7), 1 우 (MNHN). Sweden. Höör distr., 16.VI.1938, coll. D. M. S. P. \& J. F. P., B. M., $10^{7}$ (NHM). Röstanga, 4.VII.1938, coll. D. M. S. P. \& J. F. P., B. M., $10^{7}$ (NHM). Fjellfota sjö, 7.VIII.1938, coll. D. M. S. P. \& J. F. P., $20^{\prime \prime}$ (NHM).

Biology. - Known to attack Hemerobius sp. and Wesmaleius subnebulosus (Neuroptera: Hemerobiidae) (Ferguson 1986). 

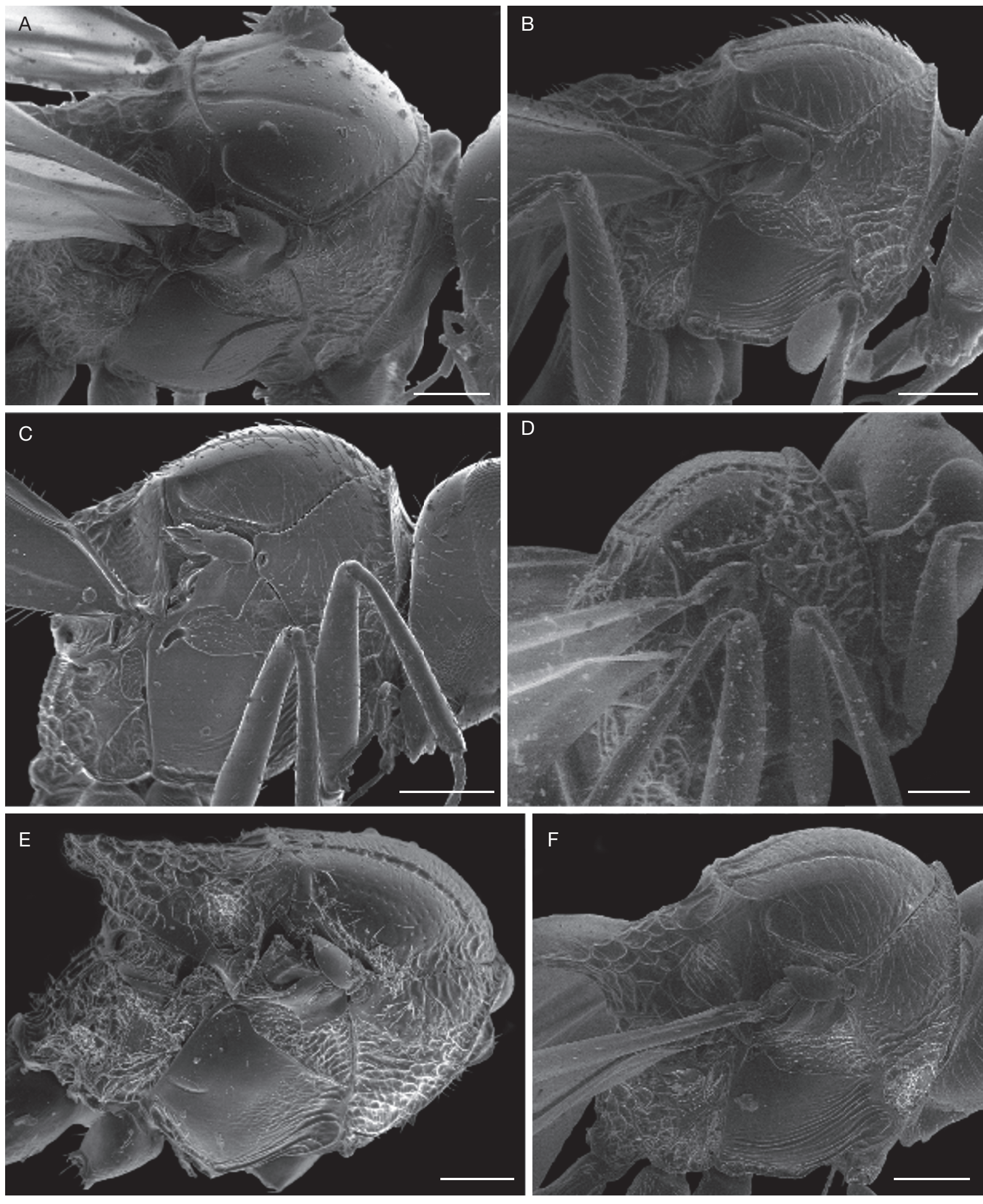

FIG. 2. - Mesosoma in lateral view of: A, Xyalaspis armata (Giraud, 1860); B, Xyalaspis laevigata Hartig, 1843; C, Xyalaspis hyalina Belizin, 1951; D, Xyalaspis rugosa Hartig, 1843; E, Xyalaspis petiolata Kieffer, 1901; F, Xyalaspis pseudolaevigata n. sp. Scale bars: $200 \mu \mathrm{m}$. 
Distribution. - Palaearctic. Known from Britain (Cameron 1883; Kieffer 1901) and Ireland (Ferguson 1986); first records from France and Sweden.

DIAGNOSIS. - Species belonging to the group of Xyalaspis having a weak carinated sculpture on the mesoscutum like $X$. arapahoe Mata-Casanova \& Pujade-Villar, 2014, X. flavipes Ashmead, 1896 and $X$ rugosus, but clearly different from these species and all other Xyalaspis species in having scutellar spine rounded in dorsal view and an elongated mesoscutum (scutellar spine highly variable in length but always spike-ended and mesoscutum wider than long other Xyalaspis species)

\section{REDESCRIPTION}

Length

Body $3.3 \mathrm{~mm}$. Wings $2.9 \mathrm{~mm}$. Antennae $2.9 \mathrm{~mm}\left(\mathrm{o}^{7}\right)$, $2.6 \mathrm{~mm}($ ( ) $)$.

\section{Coloration}

Head, mesosoma and metasoma black. Mandibles yellowishbrown with darker teeth. Antennae dark yellowish-brown. Legs yellowish-brown with darker coxae. Wing venation dark brown.

\section{Head}

Width of head $1.2 \times$ its height in front view and 2 its length in dorsal view. Face smooth, shiny and pubescent, with abundant piliferous punctae. Malar sulcus present, coriaceous, $0.7 \times$ height of compound eye. Transfacial line $1.2 \times$ height of compound eye. Diameter of toruli larger than inter-toruli distance and torulus to compound eye distance. Clypeus short; smooth, glabrous and convex. Occipital and postocular carinae absent. Compound eyes almost glabrous except for a few short setae. In females, POL:OOL:LOL ratio $=7: 5: 3$, ocelli diameter 3; in males, POL:OOL:LOL ratio $=7.5: 5: 3$, ocelli diameter 3.5 . Frons smooth, shiny and shortly pubescent with some punctae.

\section{Antennae}

Flagellomeres cylindrical and hairy. Male antennal formula (type material only has F1 to F10, but other specimens with complete antennae have been used to complete the antennal formula): 9(3.5), 4(3.5), 10(3.5), 11(3.5), 11(3.5), 10(3.5), 10(3), 10(3), 9(3), 8(3), 8(3), 7.5(2.5), 7(2.5), 9(2.5). Female antennal formula: 11(4.5), 4(3.5), 12(2.5), 10.5(3), 9.5(3), 8.5(3), 8(3), 7(3), 7(3.5), 6.5(3.5), 6(3.5), 5.5(3.5), 9.5(3.5). Placodeal sensilla in start at F3 females and at F1 in males; they are abundant in males but scarce in females.

\section{Mesosoma}

Pronotum alutaceous and laterally carinated (Fig. 2E). Mesoscutum 0.9 wider than long in dorsal view (Figs 1D; 3A, B). Mesoscutum sculpture highly variable between notauli: from smooth with slightly coriaceous and carinated sculpture at base of notauli (Fig. 3A) to completely alutaceous and carinated except for central mesoscutum (Fig. 3B). Notauli complete with transverse carinated sculpture; median mesoscutal furrow apparent. Region between external edge of notauli and margins of mesoscutum smooth and punctate. Parapsidal signum and parascutal sulcus present but weak. Scutellum $0.8 \times$ mesoscutum length in dorsal view. Scutellum coriaceous and heavily areolate. Scutellar foveae alutaceous, weakly defined by a basal carina. Interfoveal line complete. Lateral pits of scutellar foveae absent. Scutellar spine one-quarter of entire length of scutellum; rounded in dorsal view (Figs 1D; 3A, B) and straight in lateral view. Mesopleuron smooth, glabrous and shiny, lower transverse carinae becoming alutaceous as they reach the posterior mesopleuron; mesopleural triangle smooth with vertical carinae. Propodeum coriaceous, heavily areolate and pubescent; central area divided by a central longitudinal carina and several transverse carinae which define eight coriaceous cells.

\section{Wings}

Radial cell of forewing closed, 2.2 longer than wide. Marginal pubescence of forewing denser in apical third.

\section{Metasoma}

Petiole longer than wide, carinated on all sides (Fig. 4B). Third abdominal tergum $2.2 \times$ longer than the fourth abdominal tergum in dorsal view. T5 and T6 in dorsal view. Metasoma smooth and glabrous; anterior margin of T4-T7 punctuate.

\section{REMARKS}

Cameron (1883) misidentified the collected British material and placed it under the designation Aegilips subulifera. Kieffer found that those specimens belong to a different species and described them as Xyalaspis petiolata (Ferguson 1986). Regarding their morphological variability, most of the studied specimens present an alutaceous strip in the back of the internal edge of the compound eye, but this strip is variable in extension and can be absent in some specimens, hence it has been discarded for the recognition of the species.

\section{Xyalaspis pseudolaevigata \\ Mata-Casanova \& Pujade-Villar, n. sp. (Figs 1E, G; 2F)}

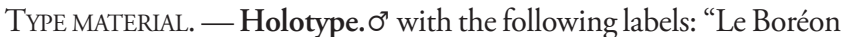
(France, Valdeblore), 1549 m, Malaise trap, 24.VII-13.VIII.2009: 10 " (white label), "Xyalaspis pseudolaevigata Mata-Casanova \& Pujade-Villar n. sp., design Mata-Casanova-2013” (red label). Deposited in MNHN. Sample code (M09-BOR1400-M2-T4).

Paratypes. (1407): Htes. Alp. Brunissard, 19.7.90, coll. Bouček, $10^{7}$ (BMNH). Vallon de Sestrière, Saint-Dalmas-le-Selvage, $1966 \mathrm{~m}$, Malaise trap, 23.VII-07.VIII.2009 (M09-SES2000-M1-T4), $30^{7}$ (MNHN); same locality, same trap, 07-19.VIII.2009 (M09SES2000-M1-T4), $20^{7}$ (MNHN). Col de Salèse, Valdeblore, Malaise trap, 2032 m, 24.VII-13.VIII.2009 (M09-BOR2000-M2T4), $10^{7}$ (MNHN); same locality, same trap, 13-27.VIII.2009 (M09-BOR2000-M2-T5), 40" (MNHN); same locality, Malaise trap, $2058 \mathrm{~m}, 13-27$. VIII.2009 (M09-BOR2000-M1-T5), $20^{7}$ (MNHN). Le Boréon, Valdeblore, $1540 \mathrm{~m}$, Malaise trap, 13-27. VIII.2009 (M09-BOR1400-M1-T5), $10^{\text {"7 }}$ (MNHN).

ETymology. - The specific epithet makes reference to the close resemblance to $X$. laevigata.

BIOLOGY. - Unknown.

Distribution. - Palaearctic. Only recorded from France. 

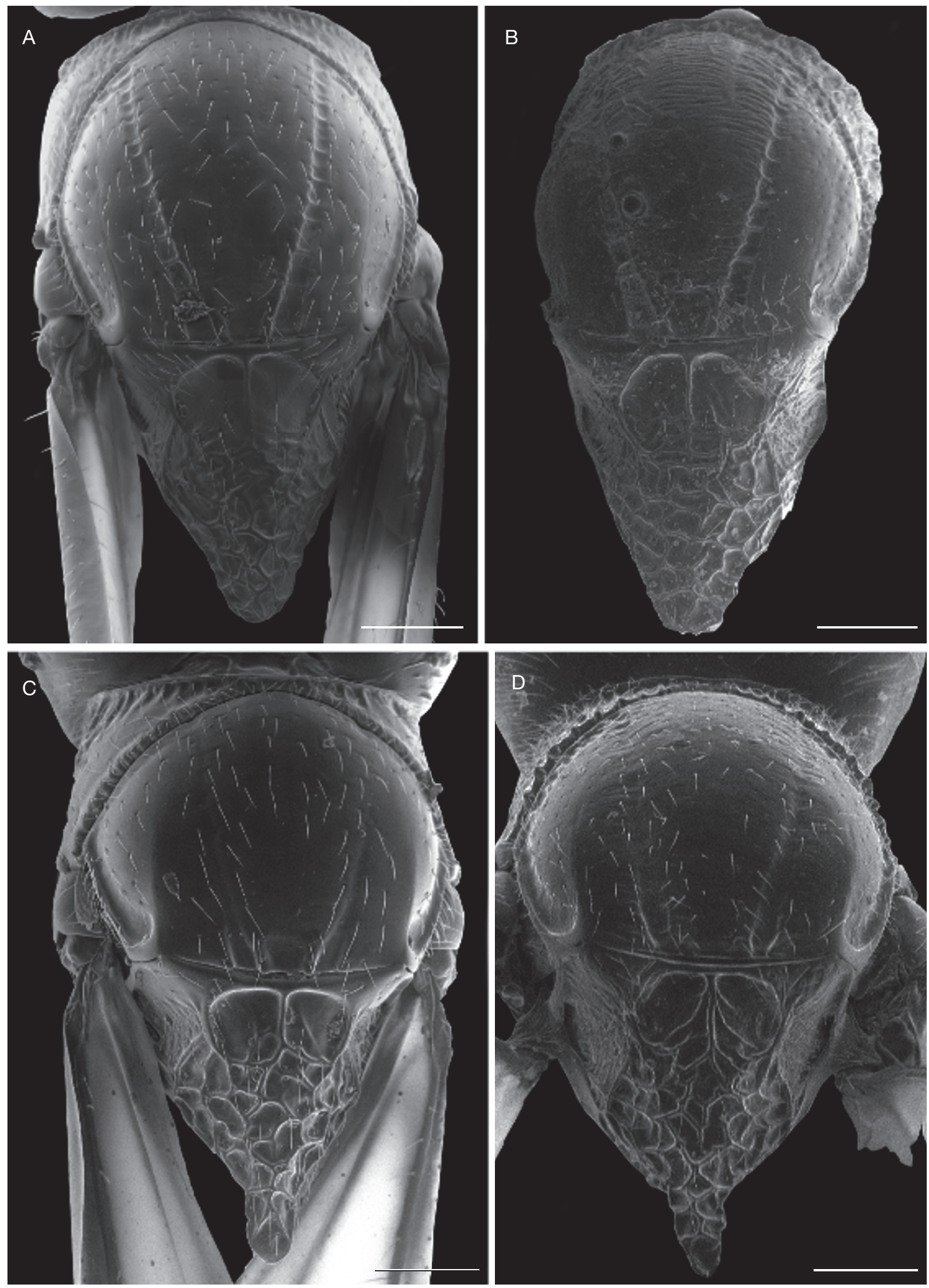

FIG. 3. - Mesoscutum sculpture variability in: A, B, Xyalaspis petiolata Kieffer, 1901; C, D Xyalaspis laevigata Hartig, 1843. Scale bars: 200 um. 
Diagnosis. - Species morphologically close to $X$. laevigata, but differs in having mesoscutum heavily carinated along its entire length and internally carinated notauli (only slightly carinated, notauli nearly disappearing in the anterior region of the mesoscutum and not internally carinated in $X$. laevigata), and darker coloration with brownish to black legs and antennae and smoked wing (legs and antennae yellowish and wings hyaline in $X$. laevigata).

\section{DESCRIPTION}

Length

Body $2.5 \mathrm{~mm}$. Wings $2.6 \mathrm{~mm}$. Antenna $2.8 \mathrm{~mm}\left(\mathrm{o}^{7}\right)$.

\section{Coloration}

Head, mesosoma and metasoma black. Mandibles yellowishbrown with darker teeth. Antennae dark brown to black. Legs black, except yellowish at joint between femur and tibia. Wing venation dark brown, wing membrane smoked.

\section{Head}

Width of head $1.3 \times$ its height in front view and 2.1 its length in dorsal view. Face smooth, shiny and pubescent, with abundant piliferous punctae. Malar sulcus present, coriaceous, $0.6 \times$ height of compound eye. Transfacial line $1.1 \times$ height of compound eye. Diameter of toruli equal to inter-toruli distance and larger than torulus to compound eye distance. Clypeus short; smooth, glabrous and convex. Occipital and postocular carinae absent. Compound eyes almost glabrous except for a few short setae. In females, POL:OOL:LOL ratio $=5.5: 4: 2$, ocelli diameter 2 . Frons smooth, shiny and shortly pubescent with some punctae.

\section{Antennae}

Flagellomeres cylindrical and hairy. Male antennal formula: 8.5(4), 3.5(3.5), 9(3), 10(3), 9(3), 9(3), 8(3), 9(3), 8.5(3), 8(3), 7.5(3), 7.5(2.5), 7(2.5), 9.5(2.5). Placodeal sensilla start at F1 in males and abundant in all flagellomeres.

\section{Mesosoma}

Pronotal plate alutaceous. Pronotum alutaceous and carinated in lateral view, with weaker sculpture in its upper part (Fig. 2F). Mesoscutum 1.3 wider than long in dorsal view. Mesoscutum alutaceous, transversely carinated along its entire length (Fig. 1E, G); notauli complete and internally carinated, median mesoscutal furrow short.. Parapsidal signum present but not clearly distinguishable; parascutal sulcus weakly impressed. Scutellum coriaceous and heavily carinated. Scutellum length equal to mesoscutum length in dorsal view. Scutellar foveae large and smooth, basally defined by a carina. Interfoveal line complete. Lateral pits of scutellar foveae large but weakly impressed, not distinct. Scutellum narrowing towards base of scutellar spine; scutellar spine parallel sided, projecting downwards in males in lateral view, length of spine about one-third of the scutellum entire length. Mesopleuron carinated, glabrous and shiny, smooth only in its upper third. Mesopleural triangle coriaceous and glabrous, with oblique carinae. Propodeum coriaceous, divided into quadrangular cells delimited by carinae in its central region; cells becoming smaller in the lower propodeum.

\section{Wings}

Pubescent. Radial cell of forewing closed, 2.6 longer than wide. Marginal pubescence of forewing denser in apical third.

\section{Metasoma}

Petiole coriaceous and longer than wide. Third abdominal tergum $2.8 \times$ longer than fourth abdominal tergum in dorsal view. T5-T7 abdominal terga are visible in dorsal view. Metasoma glabrous; anterior margin of T4-T7 punctate.

\section{Xyalaspis rugosa Hartig, 1843}

(Figs 1F; 2D)

Xyalaspis rugosus Hartig, 1843: 417 (female).

Aegilips subulifera Thomson, 1862: 412 (male) n. syn.

Xyalaspis subulifera - Kieffer 1901: 161.

TYPE MATERIAL. - Holotype. 9 with the following labels: " $X y$ alaspis rugosus" (white label, handwritten); "Holotype, Xyalaspis rugosus \%, Hartig, 1843, det. J. P-V 2009” (red label). (Deposited in ZSM).

Lectotype. O" with the following labels: "Subulifera" (white label, handwritten); "Typ" (red label); "Lectotypus Aegilips subulifera o" Thomson, 1862, desig. N. Mata-Casanova, 2012" (red label); "Xyalaspis subulifera (Thomson) o" Kieffer, 1901, det. N. MataCasanova, 2012" (white label). (Deposited in Lund University).

OTHER MATERIAL EXAMINED. - France. Vallon de Saint-Dalmas, Saint-Dalmas-le-Selvage, Alpes-Maritimes, Malaise trap, $1421 \mathrm{~m}$, 10-23.VII.2009 (M09-SES1400-M2-T3), $10^{\pi}$ (MNHN).

Switzerland. Santa Maria, Müstairtal, 1400 m, 27.VI.1960, coll. J. E. \& R. B. Benson, $10^{\text {7 }}$ (NHM).

Biology. - Unknown.

Distribution. - Palaearctic. Known from Sweden (Thomson 1862); Austria (Kieffer 1898); Norway (Hedicke 1930), Netherlands (Evenhuis 1965); first records for France and Switzerland.

DiAGNOSIS. - Species belonging to the group of Xyalaspis having a transversely carinated mesoscutum (X. aberrans Mata-Casanova \& Pujade-Villar, 2014, X. alveolata Mata-Casanova \& Pujade-Villar, 2014, X. arapahoe, X. flavipes, X. hirsuta Mata-Casanova \& PujadeVillar, 2014, and X. victoriensis New, 1979 (X. victoriensis); it can be distinguished from all these species except $X$. arapahoe by the presence of a long scutellar spine. It differs from $X$ arapahoe in presentin a median mesoscutal furrow, lateral pits and basal carina of scutellar foveae (all absent in $X$. arapahoe).

\section{REDESCRIPTION}

Length

Body $2.7 \mathrm{~mm}$. Wings $2.8 \mathrm{~mm}$. Antennae $1.95 \mathrm{~mm}$ ( $\odot$, F6 to F11 absent), $2.8 \mathrm{~mm}\left(\mathrm{o}^{7}\right)$.

\section{Coloration}

Head, mesosoma and metasoma black. Mandibles yellowish brown with darker teeth. Antennae yellowishbrown. Legs yellowish-brown with darker coxae. Wing venation yellow. 

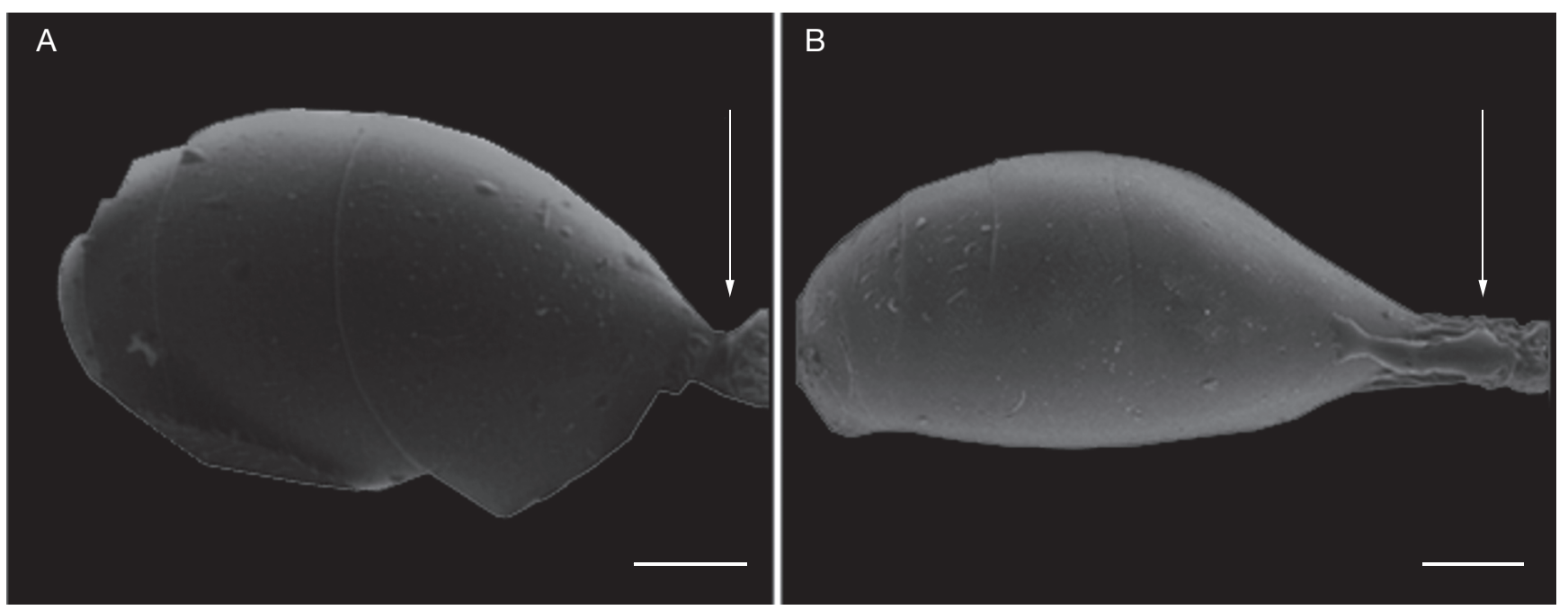

FIG. 4. - Metasoma of: A, Xyalaspis armata (Giraud, 1860); B, Xyalaspis petiolata Kieffer, 1901; arrows marking the petiole. Scale bars: 200 um.

\section{Head}

Width of head $1.3 \times$ its height in front view and $2.5 \times$ its length in dorsal view. Face smooth, shiny and pubescent, with abundant piliferous punctures. Malar sulcus present, coriaceous, $0.8 \times$ height of compound eye. Transfacial line $1.2 \times$ height of compound eye. Diameter of toruli larger than inter-toruli distance and torulus to compound eye distance. Clypeus short; smooth, glabrous and convex. Occipital and postocular carinae absent. Compound eyes almost glabrous except for few short setae. In females, POL:OOL:LOL ratio $=7: 5: 3$, ocelli diameter 2 ; in males, POL:OOL:LOL ratio $=$ 7.5:6.5:3, ocelli diameter 3. Frons smooth, shiny and shortly pubescent with some punctae.

\section{Antennae}

Flagellomeres cylindrical and hairy. Female antennal formula (flagellomeres absent from F6 onwards): 11.5(4.5), 4.5(3.5), 11(2.5), 13(3), 11(3), 12(3), 10(3), 9(3). Male antennal formula: 9(3.5), 4(3.5), 10(3.5), 11(3.5), 11(3.5), 10(3.5), 10(3), 10(3), 9(3), 8(3), 8(3), 7.5(2.5), 7(2.5), 9(2.5). Placodeal sensilla start at F3 in females and at F1 in males.

\section{Mesosoma}

Pronotum alutaceous, heavily sculptured with irregular ridges (Fig. 2D). Mesoscutum 1.3 wider than long in dorsal view. Mesoscutum transversely carinated over its entire length, carinae weaker in the central region (Fig. 1F). Notauli complete with transverse carinated sculpture; median mesoscutal furrow short and weakly impressed. Lateral region of mesoscutum smooth and punctate, parapsidal signum and parascutal sulcus present and distinct. Scutellum as long as mesoscutum in dorsal view. Scutellum coriaceous and heavily areolate. Scutellar foveae large and smooth, basally defined by a carina. Interfoveal line complete. Lateral pits of the scutellar foveae large and distinct. Scutellum narrowing towards base of scutellar spine; scutellar spine parallel sided and clearly projecting from scutellum (Fig. 1F), nearly half as long as scutellum; straight in lateral view. Mesopleuron smooth, glabrous and shiny in its upper half and heavily carinated in its lower half; mesopleural triangle large, alutaceous and glabrous. Propodeum alutaceous, central area delimited by two slightly curved carinae and divided by an irregular longitudinal carinae and several transverse carinae.

\section{Wings}

Radial cell of forewing closed, 2.4 longer than wide. Marginal pubescence of forewing denser inapical third.

\section{Metasoma}

Petiole longer than wide, carinated and alutaceous on all sides. Third abdominal tergum $3.7 \times$ longer than fourth abdominal tergum in dorsal view. T5 and T6 abdominal terga visible in dorsal view. Metasoma smooth and glabrous; anterior margin of T4-T7 punctate.

\section{REMARKS}

After examining the type material of both species and undetermined material, we conclude that $X$. subulifera is a junior synonymy of $X$. rugosa. Both present same carinated sculpture of the mesoscutum and a long, clearly projected scutellar spine.

\section{DISCUSSION}

Hedicke (1914) described Omalaspis laevis from Féchain, France. This species was transferred to the genus Xyalaspis by Ros-Farré \& Pujade-Villar (2011). After examining the type material (10 deposited in MNHN) we concluded that this species belongs to Aegilips. It therefore becomes Aegilips laevis (Hedicke, 1914) n. comb., leaving six species of Xyalaspis in the Western Palaearctic: $X$. armata, X. hyalina, X. laevigata, $X$. petiolata, $X$. pseudolaevigata Mata-Casanova \& PujadeVillar, n. sp. and $X$. rugosa. 
1. Mesoscutum longer than wide, scutellar spine rounded in dorsal view, never projected (Figs 1D; 3A, B)........

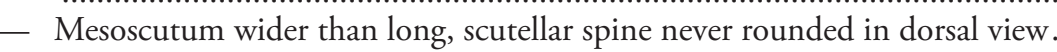

2. Mesoscutum smooth or only weakly carinated (Fig. 1A-C) .....

— Mesoscutum transversely carinated over its entire length (Fig. 1E-G) .....

3. Mesoscutum completely smooth (Fig. 1A), petiole wider than long (Fig. 4A)........... armata (Giraud, 1860)

- Mesoscutum always presenting weak transverse carinae at base of notauli (Fig. 1B, C), petiole as long as wide or longer than wide.....

.. 4

4. Notauli disappeared in anterior part of mesoscutum, transverse carinae reduced to base and edges of the notauli (Fig. 1B), antennae longer than body $X$. hyalina Belizin, 1951

- Notauli fading in anterior part of mesoscutum but not entirely disappearing (Figs 1C; 3C, D), transverse carinae highly variable in extension from the base of notauli (Figs 1C; 3C) to the entire surface of mesoscutum (Fig. 3D), antennae shorter than body X. laevigata Hartig, 1843

5. Scutellar spine clearly distinguishable from mesoscutellum (Fig. 1F), legs and antennae yellowish, wings hyaline X. rugosa Hartig, 1843

- Scutellar spine not clearly distinguishable from mesoscutellum (Fig. 1E, G), legs and antennae black, wings smoked $X$ pseudolaevigata Mata-Casanova \& Pujade-Villar, n. sp.

The mesoscutum sculpture of the Xyalaspis species included in this study is not as highly variable as in the Neotropical species, although they still present variability and this feature has a key role in differentiating the species. The mesoscutum of $X$. armata is smooth, with no internal sculpture in the notauli (Fig. 1A). X. hyalina and X. laevigata have an overall smooth mesoscutum, although it is slightly carinated at the base of the notauli in $X$. hyalina (Fig. 1B) and has a more extended carinated sculpture in X. laevigata (Figs 1C; 3C, D). Both species present weakly impressed notauli that vanish in the anterior third in $X$. hyalina. $X$. petiolata presents high variability in the mesoscutal sculpture, from some weak carinae reduced at the base of the notauli (Fig. 3A) to a completely carinate mesoscutum (Fig. 3B), although the carinated sculpture of the central region is weaker. Finally, $X$. rugosa (Fig. $1 F$ ) and $X$. pseudolaevigata Mata-Casanova \& Pujade-Villar, n. sp. (Fig. 1E, G) present transversely carinated sculpturing on the entire mesoscutum surface.

The scutellar spine is also highly variable between species. In $X$. petiolata it is rounded and not spiked while in the rest of the studied species it projects and forms a spike (Figs 1D; 3A, B). In $X$. hyalina the scutellar spine is not clearly distinguished from the mesoscutellum (Fig. 1B); in $X$ armata (Fig. 1A), $X$. laevigata (Fig. 1C) and X. pseudolaevigata Mata-Casanova \& Pujade-Villar, n. sp. (Fig. 1E, G) the mesoscutellum narrows toward the base of the scutellar spine; in X. rugosa the scutellar spine has parallel edges and is clearly distinguishable from the mesoscutellum (Fig. 1F). As mentioned earlier, the presence of a true scutellar spine allows to separation of Xyalaspis from Aegilips. However, it is interesting to note that some individuals of $X$. laevigata and $X$. petiolata present remains of the circumscutellar carina.

With regard to the distribution of the species examined in this study, the data obtained indicate that Xyalaspis hyalina has a range from Cyprus to Tadjikistan, being the easternmost of the Xyalaspis species present in the Western Palaearctic region. $X$. laevigata, previously cited only from Austria, is here recorded for the first time from Spain, Andorra, France, Germany, Norway, Romania and Iran, extending its distribution across the European continent and reaching the Middle East. The distribution of $X$. petiolata, previously known only from the British Isles, is expanded to include France and Sweden. The distribution of $X$. rugosa, previously known from Austria, is expanded to Britain, Norway, Sweden, the Netherlands and, after being synonymized with $X$. subulifera, it is cited for the first time from France and Switzerland, making it the most widespread species of Xyalaspis on the European continent. Although there are no new records for $X$. armata, this species is widely distributed across Europe, being cited in the British Isles, Sweden, Germany, Austria and Russia. Xyalaspis pseudolaevigata Mata-Casanova \& Pujade-Villar, n. sp. is only known from France; all but one of the available records come from the Mercantour National Park. It is noteworthy that for all species collected in the Mercantour National Park most of the specimens collected were males; the sole specimen of $X$. petiolata obtained was also the only female represented in the collections studied here. The female of $X$. pseudolaevigata Mata-Casanova \& Pujade-Villar, n. sp. remains unknown.

The biology of Xyalaspis is still poorly understood in regions where this genus occurs. Although it is known that Xyalaspis petiolata attacks the aphid-feeding larvae of Wesmaelius subnebulosus and Hemerobius sp. (Neuroptera: Hemerobiidae), the hosts of the other five species remain unknown. Palaearctic Xyalaspis species have a wide range of suitable hosts, with 170 species of Hemerobiidae reported, most of them from the Western Palaearctic (Makarkin, 1995). More research must be undertaken to fully understand thei biology of Xyalaspis. 


\section{Acknowledgements}

The All Taxa Biodiversity Inventory + Monotoring Mercantour / Alpi Marittime was launched by the European Distributed Institute of Taxonomy (EDIT) project (2006-2011).

Some specimens studied in this paper were collected as part the Terrestrial Invertebrates Module set up by the Muséum national d'Histoire naturelle, Paris, during which malaise trap samples were obtained by J. Molto, M. Torjman and E. Minssieux (Mercantour National Park) and sorted to family level by M. Czyrnek and T. Théry (MNHN).

We thank M.-F. Leccia (Mercantour National Park) and M. De Biaggi (Parco Alpi Marittime).

We also thank C. Villemant (MNHN) for type of X. armata, Oleg Kovalev and Sergey Belokobylskij (ZIN) for the type of $X$. hyalina, Olga Schmidt (ZSM) for the types of $X$. laevigata and $X$. rugosa, David G. Notton (BMNH) for type of $X$. petiolata, Frank Koch (Museum für Naturkunde) for the type of X. spinigera and to Roy Danielsson (Lund University) for the type of $X$. subulifera. Also John Hubert and Jennifer Read (CNCI), and David G. Notton (BNHM) for the loan of undetermined material. Finally, we would like to thank George Melika for helping us to translate the original descriptions of Belizin from Russian language. This study has been funded by project CGL2011-22889 of the Science and Innovation Ministry of Spain. We thank the reviewers that contribute to improve our manuscript.

\section{REFERENCES}

BELIZIN V. I. 1951. - Cynipidae (Hymenoptera: Cynipoidea) of the fauna of the USSR limitrophic countries. Entomologicheskoe Obozreine 31 (3-4): 573-574 (in Russian).

BELIZIN V. I. 1961. - New Figitidae (Hymenoptera: Cynipoidea) of the fauna of the USSR limitrophic countries. Entomologicheskoe Obozreine 40: 153-164 (in Russian).

CAMERON P. 1883. - Descriptions of sixteen new species of Parasitic Cynipidae, chiefly from Scotland. Transactions of the Entomological Society of London 16: 365-374.

Dalla-Torre K. W. \& KiefFER J. J. 1910. - Das Tierreich XXIV: Cynipidae. R. Friedlander \& Sons, Berlin, 24: 47-50 (in German).

Deharveng L., Bedos A., Daugeron C., Villemant C. \& JudSON M. L. I. 2015. — Organization, usefulness and limitations of an ATBI (All Taxa Biodiversity Inventory): the inventory of terrestrial invertebrates in the Mercantour National Park, in Daugeron C., Deharveng L., Isaia M., Villemant C. \& Judson M. (eds), Mercantour/Alpi Marittime All Taxa Biodiversity Inventory. Zoosystema 37 (1): 9-30. http://dx.doi.org/10.5252/ z2015n1a1Fergusson N. D. M. 1986. — Charipidae, Ibaliidae \& Figitidae (Hymenoptera: Cynipoidea). Handbooks for the Identi- fication of British Insects, Vol. 8, Part 1C: 29.

FÖRSTER V. I. 1869. - About the gallwasps. Verhandlungen der Zoologisch-Botanischen Gesellschaft in Wien 19: 327-370 (in German).

HARTIG T. 1843. - Second supplement to the Natural History of Gallwasps. Zeitschrift für die Entomologie 4: 396-422.

HEDICKE V. I. 1914. - Contributions to the knowledge of cynipides. Deutsche Entomologische Zeitschrift 59: 634-637 (in German).

HEDICKE V. I. 1930. - Contributions to the knowledge of cynipides. Deutsche Entomologische Zeitschrift 85: 74-76 (in German).

KIEFFER V. I. 1898. - About a new and previously known cynipides. Wiener Entomologische Zeitung 17: 257-267 (in German). Kieffer J. J. 1901. Revision of Onychiinae. Bulletin de la Société Entomologique de France 7: 161 (in French).

MaKarkin V. N. 1995. - Notes on Palaearctic Hemerobiidae (Neuroptera). I. Introduction and genus Wesmaelius Kruger, 1922. Part 1. Subgenus Wesmaelius. Far Eastern Entomologist 24: 1-13.

Mata-Casanova N. \& PUjade-VIllar J. 2013. - Acanthaegilopsis malagasy gen. n. and sp. n. of Anacharitinae (Hymenoptera: Cynipoidea: Figitidae) from Madagascar and the Comoros. African Entomology 21 (1): 161-164.

Mata-Casanova N., Selfa J. \& Pujade-Villar J. 2014a. - Revision of the American species of Genus Xyalaspis (Hymenoptera: Figitidae: Anacharitinae). Annals of the Entomological Society of America 107 (3): 557-566.

Mata-Casanova N., Selfa J. \& Pujade-Villar J. 2014b. Revision of the Asian species of genus Xyalaspis Hartig, 1843 (Hymenoptera: Figitidae: Anacharitinae). Journal of Asia-Pacific Entomology 17 (2014): 569-576.

ReINHARD H. 1860. - The Figitidae of Central Europe. Berliner Entomologische Zeitschrift 4: 204-264.

Restrepo-Ortiz C. X. \& Pujade-Villar J. 2010. — The validity of Hexacharis Kieffer with taxonomic notes on the Anacharitinae Genera (Hymenoptera: Cynipoidea: Figitidae). Zootaxa 2400: $16-28$

RiCHARDS O. W. 1977. - Hymenoptera. Introduction and key to families. $2^{\mathrm{a}} \mathrm{ed}$. in Handbooks for the Identification of British Insects. London, British Museum/ Royal Entomological Society, V. 6, pt.1, p. 1-100.

RONQUIST F. 1995. - Phylogeny and early evolution of the Cynipoidea (Hymenoptera). Systematic Entomology 20: 309-335.

Ros-FarRé P. \& PUJADE-VILLAR J. 1997. — Figitids sensu stricto found in the iberian península (Hymenoptera, Figitidae: Figitinae, Anacharitinae, Aspicerinae). Sessions Conjuntes d'Entomologia, Institució Catalana d'Història Natural-Societat Catalana de Lepidopterologia 10: 123-134 (in Catalan).

Ros-Farré P. \& Pujade-Villar J. 2011. - Revision of genus Omalaspis Giraud, 1860 (Hym.: Figitidae: Aspicerinae). Zootaxa 2917: 1-28

Ros-Farré P., Ronquist F. \& PUJADE-VILlar J. 2000. — Redescription of Acanthaegilips Ashmead, 1897, with characterization of the Anacharitinae and Aspiceratinae (Hymenoptera: Cynipoidea: Figitidae). Zoological Journal of the Linnean Society 129: 467-488.

ThOMSON C. G. 1862. - Attempt to classify and describe the Swedish Figitides. Öfverisgt af Kongliga Svenska Vetenskaps-Akademien Förhandl 18 (9): 395-420 (in Swedish). 